\title{
A report on the scientific conference entitled Everyday life of soldiers throughout history An army en route, Lodz, June 1, 2017
}

June 1, 2017, the Institute of History of the Faculty
of Philosophy and History of the University of Lodz
held a scientific conference entitled Everyday life of soldiers throughout history. An army en route. The meeting was started by the Vice-dean for Science of the Faculty of Philosophy and History, professor Anna Marciniak-Kajzer. She emphasized, that it was an interdisciplinary conference, and wished everybody fruitful discussions. Another speaker, the Director of the Institute of History, professor Dariusz Jeziorny, underlined the importance of military issues. The chairman of the organizational committee, professor Jarosław Kita, also greeted the participants of the meeting.

Thirteen speakers from seven academic centers (University of Lodz, Catholic University of Lublin, Cardinal Stefan Wyszyński University in Warsaw, Jan Kochanowski University in Kielce - Piotrków Trybunalski's branch, War Studies University, Jan Długosz University in Częstochowa, as well as Pomeranian University in Słupsk) met in Lodz.

The conference covered rarely-discussed issues of a movement of troops throughout the ages. Such issues as organization of marches, field obstacles, means of transport, discipline, as well as logistic facilities were discussed. Organizers decided to present all papers according to their chronology and the problem they described, thus dividing the meeting into three parts.

The first part of the debate began with a speech of Kirił Marinow Ph.D. entitled Crossing forests and ravines: struggles of the Byzantine army in a difficult terrain in the light of the Constitution Nine of the Taktika by Leo VI the Wise. The speaker described emperor's 
recommendations for the Byzantine army for difficult areas, such as ravines or forests. Then, professor Jan Szymczak delivered a speech entitled From the castle to the war camp. Horseback, armed and well stocked. He talked about knights' preparations and equipment for a war expedition, especially means of transport (horses, carts), food, as well as accommodation. The presentation was complemented by illustrations. Tadeusz Grabarczyk Ph.D., in turn, concentrated on water obstacles for medieval armies ("On dry feet" or "jumping into the waves". The crossing of rivers by the Polish army from the $11^{\text {th }}$ to the beginning of the $16^{\text {th }}$ century). On selected examples he showed difficulties which armies in the Middle Ages had to overcome, i.e. the width and depth of the river, the need to build bridges, atmospheric conditions. Andrzej Niewiński Ph.D. (Road to war. Military preparations in selected medieval sources) was a last lecturer of the first part of the conference. He dealt with issues related to war preparations as described in medieval sources.

Professor Aleksander Bołdyrew was a first speaker of the second session, as he described the importance of Polish military troops in the era of the last Jagiellons (The tabor equipment in a movement of the mercenary army in Poland of the last Jagiellons). The lecturer referred to an equipment the army used during the expedition (war wagons), as well as its manufacturers. Jędrzej Kałużny M.A. talked about municipal war wagons from Łęczyca and Sieradz, which were used by the Kingdom of Poland's army (Municipal war wagons in the army of the Kingdom of Poland in the $16^{\text {th }}$ and $17^{\text {th }}$ centuries). On the other hand, Zbigniew Hundert Ph.D. presented crown and field guards and their role in the army, both from military and political point of view (Offices of grand and field guard in Jan Sobieski's era. The people who organized marches of the crown army). Another lecturer, professor Jarosław Kita, focused on movement challenges for insurgents during the January national liberation uprising. He discussed the scarcity of logistic facilities or supply for insurgent troops, as well as hygiene conditions of insurgents (Movement of insurgent parties during the January uprising).

The third part consisted of five papers. Lieutenant colonel Jacek Lasota Ph.D., on the basis of his own experience, informed the audience how to overcome water obstacles using tanks (The overcoming of a water obstacle under water by subdivisions using tanks - theory and practice). The presentation was complemented with many illustrations and numerous anecdotes. Another speaker, 
professor Robert Majzner, analyzed observations and conclusions drawn from reports of the Second Department of Polish General Staff as regards events in Abyssinia and a civil war in Spain, and their influence on an evolution of the art of war of Polish armed forces (Abyssinian and Spanish observations of the Department of Polish General Staff concerning the mobilization and military supply of the army on the battlefield in the years 1935-1939). The next speaker, professor Witold Jarno, presented the automotive service of the Polish army and its tasks just before the outbreak of the World War II. On the other hand, Marek Brylew Ph.D. discussed the importance of the logistic supply unit for military contingents carrying out tasks outside Poland (The role and tasks of the logistic supply unit in supporting Polish military contingents implementing tasks outside the borders of the country). Then, Magdalena Pogońska-Pol Ph.D. described concepts and plans for crossing the Suez Canal on the eve of the fourth Arab-Israeli War of October 1973 (A canal to conquest. Egyptian assumptions of crossing the Suez Canal on the eve of the 1973 October war).

The diversity of the subject and the nature of speeches prompted participants of the conference, as well as students of the Institute of History, to start a heated discussion. It turned out, that time allotted for it after each part was insufficient.

Finally, professor Jarosław Kita stated, that the meeting undoubtedly fulfilled its purpose, as its participants had a chance to exchange views on the movement of an army throughout history. The debate was closed by professor Dariusz Jeziorny, who invited the audience to another conference.

Magdalena Pogońska-Pol UNIVERSITY OF LODZ*

* The Faculty of Philosophy and History, The Institute of History, The Department of History of Poland and World after 1945 / Wydział Filozoficzno-Historyczny, Instytut Historii, Katedra Historii Polski i Świata po 1945 r., e-mail: mpogon@op.pl; mpogon skapol@uni.lodz.pl. 